\title{
Migration-induced Variation in the Communicative Space
}

Thomas Krefeld ${ }^{a}$

\begin{abstract}
Migration is one of the fundamental and widespread causes of linguistic contact and variation induced by contact. Although contact-induced linguistic variation is not uncommon, it requires explanation within a model that allows the linguistic data to be contextualized in the communicative space. It requires the localization of language variation from the speaker in his/her historical context (with his/her variety repertoire, his/her communicative routines and the effect of this communicative routines in his/her own repertoire). In this sense, the speaker represents a minimal unit of the communicative space ('glossotope') in which it is inserted.
\end{abstract}

Keywords: Language Variation. Migration. Glossotope. Perception. Variational Linguistics. 


\section{Speaker, Speech, Language}

The basic categories of linguistic description are the individual speaker, the concrete speech and the conventionalized system of the language. And this way, even beyond linguistics, the basic categories for the description of every cultural technique are identified: the individual, the interaction and the convention ${ }^{1}$. However, language - in contrast to most other (or perhaps all) cultural techniques - is deeply anchored in the human cognitive neurophysiology. Expressed in the form of a computer metaphor, language is part of both the human hardware and software systems. But exactly like the other conventions (in contrast to other cognitive functions), language is subject to continuous, and sometimes radically accelerated historical variation. This occurs, among other reasons, because purely conventionally based cultural techniques use language as an instrument, and their changes can therefore be transferred directly to the language. From a spatial perspective, it is important to bear in mind that the spaces in which these different cultural techniques (or conventions, including language) operate are generally not congruent. Thus, it is historically and theoretically incorrect to expect consistently congruent cultural and theoretical spaces. Such a flawed viewpoint is the result of ideological prejudices: on the one hand, the speaker and the speech are not considered, and on the other hand, the language is seen as a system belonging to the whole collective. However, speakers, and often also entire groups of speakers, are mobile; in the wake of migration, they change their repertoires. They become multilingual, they acculturate towards monolinguals and multilinguals with different repertoires who themselves possibly undergo a process of acculturation.

${ }^{1}$ This formal trinity holds for several disciplines and might be substantiated, for literature (author, text, genre), religion (believer, religious practice, confession), jurisprudence (legal person, behavior, law system) etc.

\section{Variational Linguistics and Linguistics of Varieties}

Obvious, and often confusing, variability polarizes linguists, because it can only partially be formalized. It is therefore preferable to some to use theoretical frameworks to make it disappear; this is achieved most simply by reducing the scientific object to an innate Universal Grammar. However, for those interested in the study of language change, 
2 The preferences seem to follow disciplinary traditions; German philology shows a tendency to use, variational linguistics (cf. PURSCHKE, 2011), whereas Romance philology tends to 'linguistics of variety' (cf. SINNER, 2014; STEHL, 2012 may be regarded as an exception).

3 This felicitous $\mathrm{met}$ a p or was proposed by Žarko Muljačić when talking of transsatellizzazioneo of former autonomous idioms; see the synthesis in MULJAČIIĆ, 1993, p. 93.

${ }^{4}$ It is certainly not by accident that dialectology in the German speaking academic context did not evolve into multidimensional variational linguistics; this methodological progress was blocked by an idealized conception of dialect, seen as a homogenous and consistent linguistic system. This is not true for Italy, where Benvenuto Terracini (1914-1922) developed a multidimensional f r a m e work for dialectology which is still influencing research in the domain of variation and sociolinguistic dynamics of language. linguistic variation plays an important role and for variational linguistics it is actually the real object of science. Even a second subdiscipline, i.e. linguistics of varieties came up, although these two approaches are not strictly discrete (cf. SINNER, 2014, p. 11-17); indeed, one can to some degree identify complementary avenues of study among these differing research traditions (exemplified by the works of William Labov on one side, and Eugenio Coseriu on the other). ${ }^{2}$ Both expressions have quite different emphases: variational linguistics is decidedly processoriented; at its core is the formation and spread of variants (or features) and therefore it is more closely concerned with diachrony and empirically attested speech and the biographical context of the speaker in space and time; the linguist who focuses on migration is examining variation, and is in this regard doing variational linguistics.

In contrast, variety linguistics is concerned with the aggregation of variants resulting in new varieties. The prime example of a variety is the geographically defined dialect, which can be described as a functioning (i.e. complete and semiotically autonomous) language. The relationship of a dialect as a geographically defined variety to a standard variety (or language) spoken in a larger space and encompassing any number of dialects (for example standard German or Italian) has nothing to do with the emergence of the dialectal forms, but rather represents the socio-linguistic product of historical changes, which determine the language system of the dialect as a whole and turn it into a 'satellite's. Furthermore, local dialects themselves reflect their own distinct internal variation, as Louis Gauchat describes in minute detail in his paper on the Franco-Provençal dialect of Charmey - a village that at that time (1905) was only reachable on foot. This study could have been groundbreaking, had it received the attention it deserved. Though a complete description of its conclusions cannot be outlined here, it describes a wide variety of sources of variation (using modern terminology) and dimensions of markedness ${ }^{4}$. His conclusions in brief:

[...] il importe de constater qu'à Charmey, où toutes les conditions sont plutôt favorables à l'unité, la diversité est beaucoup plus forte que je ne me le serais imaginé après une courte visite. [...] L'unité du patois de Charmey, après un examen plus attentif, est nulle [...] (GAUCHAT, 1905, p. 48) 
The question of varieties stemming from migration is of particular interest to the linguist; however, they cannot amply be investigated until the second, or even the third generation. Migration-induced varieties are therefore not spoken by the migrants themselves, but rather by their descendants. They can develop both in the "imported" language spoken by the migrants, and the languages that are regularly spoken in the respective immigration region. These varieties may also outlast the multilingualism whiche stems from migration and characterizes the following generations, such as typical "superstratum effects", e.g. the multitude of arabic features in Ibero-Romance.

\section{Variation, Variants - Variety}

Living dialects ${ }^{5}$ existing horizontally next to, or vertically below its corresponding standard language, cannot strictly speaking be described as variation, because 'variation' describes the situation where one variable manifests in multiple forms, and for complex systems it is not possible to formulate variables that encompass the entire system. At best, individual linguistic elements from multiple dialects including the standard variety can be described as spatial variants of a common historical variable or syntactic function. For example, in northern Italy, the variants [k-], [tc-], [ts-], [tf-] stem from the Latin [k-], which in this case can be described as variable. Individual forms from one variety can also be adopted by one variety from another through contact, and subsequently become variants (as in the case of regional Italian bun di 'buongiorno'). However, it is not useful to describe entire varieties - so-called minority languages, or even standard languages such as Sursilvan, Franko-Provençal, Occitan, Lombard, Standard Italian, etc.,

5 A language/ regarded as living as long as it is acquired spontaneously in every day communication and used face-to-face by all generations. This corresponds to level 6 of the language vitality scale proposed by Ethnologue (http:// www.ethnologue.com/ about/language-status; called 11/1/2015). as 'variants', because the question arises: What could be the related variable? Romance? Italo-Romance? Central Romance?

The 'horizontal' relationship between neighboring dialects and the 'vertical' relationship between a dialect and the standard language can only be conceptualized consistently as variation if the category of the 'variety' is abandoned in favor of openly varying continua.

This is hardly a convincing fundamental solution, because speakers are fully capable of immediately and holistically 
${ }^{6}$ Even so (one cannot find always caracteristic features of a dialect and clear cut borders towards neighbouring ones) all members belonging to the same dialect community have something in common. [...] When they meet abroad, it makes them recognize each other and in doing so, they show a joyful sense of home.

7 (c f. KREFELD, 2015a); spatial, i.e. situational copresence is also fundamental for Tom a sello's theory of gestural origin of language (cf. TOMASELLO, 2008). recognizing certain varieties - especially their own of course - without being directed towards certain salient features. Louis Gauchat also observed this fact, despite his clear insight into the existence of variation inside of a variety:

Man hat gesagt, ein Dialekt müsse charakteristische Merkmale enthalten, die sonst nirgends vorkommen, er müsse von den Nachbardialekten durch ein an ganz bestimmten Orten durchgehendes Zusammenfallen mehrerer (wenigstens zweier) Lautgrenzen deutlich geschieden sein. Innerhalb des Dialekts müsse eine ungetrübte lautliche Einheit herrschen. Da dies nicht vorkomme, gebe es keine Dialekte.

(...) Trotzdem besitzen alle Angehörigen eines Dialekts etwas Gemeinschaftliches ${ }^{6}$, an dem man sie erkennt, das in ihnen, wenn sie in der Fremde zusammentreffen, ein freudiges Heimatgefühl weckt. (GAUCHAT, 1903, p. 96)

The fact remains, that the theoretical status of dialects in this sense is unproblematic, and therefore in some regard privileged; dialects are consistent varieties because, firstly, the correlation of individual variants in speech and the geographic origin of a speaker is evident and such is, secondly, the belonging together of these variants representing one and the same local dialect (i.e. a local language with the variety-status of a dialect).

\section{Multi-dimensionality of Marking}

The description of a feature as locally specific, i.e. its markedness in the diatopic dimension, is naturally not sufficient, because not all variants are dialectal, and other or additional markings are not excluded; this holds true of course also within a given dialect. The following dimensions of markedness are required for sufficient description: the diastratic (according to social milieu), the diaphasic (according to the style of speech and the situational appropriateness), the diagenerational (according to age) and the medial (according to the aid of a medium). It is also misleading to classify the phonic realization likewise as "medial", because in contrast to writing or electronic media, it is substantive for the phylo- and ontogenetic structure of language in general, and therefore in contrast to the media it cannot be 'subtracted'. Insofar as spoken, and not mediated communication is only possible face-to-face, in concrete (and not metaphorical) proximity, the genuinely spatial conditioning of elementary communication is shown ${ }^{7}$. 
In light of the outlined diversity of possible markedness, crucial methodological questions arise beyond the pure diatopic; first, when attributing markers, and second, when deriving varieties. Because while the actual occurrence of a variant in speech, and the individuality of the speaker in the original communicative situation of the oral face-to-face communication is evident, the exact qualification of their marker, and above all the aggregation of similarly marked variants to varieties, prove to be empirically difficult. Accomplishing both tasks must happen under the condition that variation is not merely an object of science - and thereby a component of expert linguistic knowledge - but also belongs fundamentally to the knowledge of the speaker himself, and in this respect is grounded in layman's knowledge. From the perspective of the linguist interested in migration, one must investigate whether the subsequent generations see themselves as a 'third' group alongside the origin group of actual migrants (their parents/ancestors) and the group in their immediate surroundings. Such specific, new identities are independent of the maintenance of multilingualism. To recognize the speakers' metalinguistic knowledge, though, does not mean to consider him a linguist because the analytical categories of one and the other are, of course, fundamentally different.

\section{Two epistemological horizons}

Thus, two epistemological horizons are to be separated from one another; namely, the speaker's knowledge and the linguist's knowledge. Additionally, there is another differentiation that must be kept in mind with respect to the speaker's knowledge: first, there is the segment of 'procedural' knowledge, or the ability to do something - in this case, the ability to speak. More specifically, this refers to the natural use of a variant, be it conventionalized or in some cases even new; it can also refer to spontaneous switching between varieties or languages. Second, there is the complementary segment of 'declarative' knowledge, which can be described as representations that are associated with the variants and their usage, such as 'I understand this expression, but it is false'; or 'this expression is only used by youth in the city, older people 
in the countryside or by migrant speakers with a particular ethnic background', etc.

Procedural knowledge is still situated strongly in the foreground of linguistics, because the relevant data consist primarily, and in many cases exclusively of utterances, i.e. speech production. Declarative knowledge, however, is crucial in describing variation: In a sense, variational linguistics and linguistics of varieties are at their cores nothing more than the elevation of procedural and declarative speaker knowledge to the epistemological level of the linguist.

\section{Complementary series of data from linguistic production and perception}

In such a linguistic treatment of speaker knowledge, it is important to supplement the usual production data with a qualitatively much different data set which is drawn from the perception and production data by the speaker himself. Relevant tests, which belong to the fundamental instruments of the now well-established field of perceptive linguistics, are suited to teasing out the variation-related representations of speakers and speaker groups. It must be emphasized that the survey and analysis of perception data that are up to now quite sparse in quantity, are not a peripheral interest of questionable scientific seriousness; rather, they comprise the actual basis for the concrete definition of variation-specific markers of individual variants according to the aforementioned dimensions, such as the assumption of varieties in the sense of aggregated, co-occurring variants. Production data alone are insufficient in tackling both of these tasks.

First, there are variants that may even be typologically relevant, such as the linearization of clitic pronouns in the Italian volevo dirtelo vs. te lo volevo dire etc., without carrying any marker. The 'ground zero' of linguistic variation for linguistics of varieties is not invariance, but rather a lack of salience. In other words: markedness is conspicuousness, and as such, a phenomenon of salience (cf. PURSCHKE, 2011, p. 80-87; 90-121).

Directly connected to this, the marker of the respective variant is not firmly inscribed; instead, it proves to be dependent 
8 The shifting of markedness is much more complicated than the simple unidirectional "chain of varieties" supposed by Koch/Oesterreicher (2011, p. 16), which allows only the following way of shifting: diatopic diastratic diaphasic. Indeed, it is not difficult to find, e.g., words of dialectal origin ('diatopic') spread in late antiquity by the ecclesiastical language ('diastratic') as north ita. pieve 'parish' < lat. plebe $[\mathrm{m}])$ or dialectal expression with origin in formal and latinized varieties, as Bavarian (incl. Austrian) salutation Servus 'hi'.

${ }^{9}$ See the discussion of the accent du Havre by Hauchecorne/Ball (1997), which revealed to be nothing but a myth, or Schmid (2003) who was able to demonstrate that the conviction of speakers from Florence and Prato as being able to recognize each other was not founded at all. upon the speaker (group), and as such subject to diachronic change (see Chap. 1): markers arise, are carried from one dimension to another, and disappear ${ }^{8}$. When speakers do not associate any markers, the linguistic assumption of varieties is superfluous. On the other hand, apparent varieties - whose existence may be implied in the speaker's knowledge - can be uncovered via real perception tests (i.e. through confrontation of the speaker with authentic production data) $)^{9}$. From the perspective of migrational linguistics, one must verify the pretended - often ideologically motivated ability to recognize speakers with foreign ancestry, and to differentiate distinct regions of origin or forms of multilingualism.

\section{Inconspicuousness and construction of social identity}

The lack of perception of conspicuousness, which, as stated earlier in this article, is by no means grounded in missing variations, is a reliable indicator of the standard nature of a feature, and thus very useful for identifying regional standards. It is closely connected with the sociopsychologically and sociologically basic construction of group cohesiveness ('we'), which can be organized into different gradients of exclusivity, and may manifest pronominally (such as in the opposition of Fr. nous/It. noi vs. Fr. nous autres/It. noialtri. This phenomenon is in no way limited to generational, ideological or religious groups, but rather is often reflected in the self-designation of local dialects and migrant varieties by their speaker communities. A dialectological example of this can be found in the network of Atlante linguistico ed etnografico del Piemonte occidentale (ALEPO), in which the informants in many localities identified dialect names, which were based on the use of the $1^{\text {st }}$ person plural ('we'). The following map identifies these areas and also shows in part a very problematic, if not impossible allocation of these local dialects to the larger regional dialects and languages noted in the map legend. 
Figure 1. Allocation of local dialects to the larger regional dialects and languages
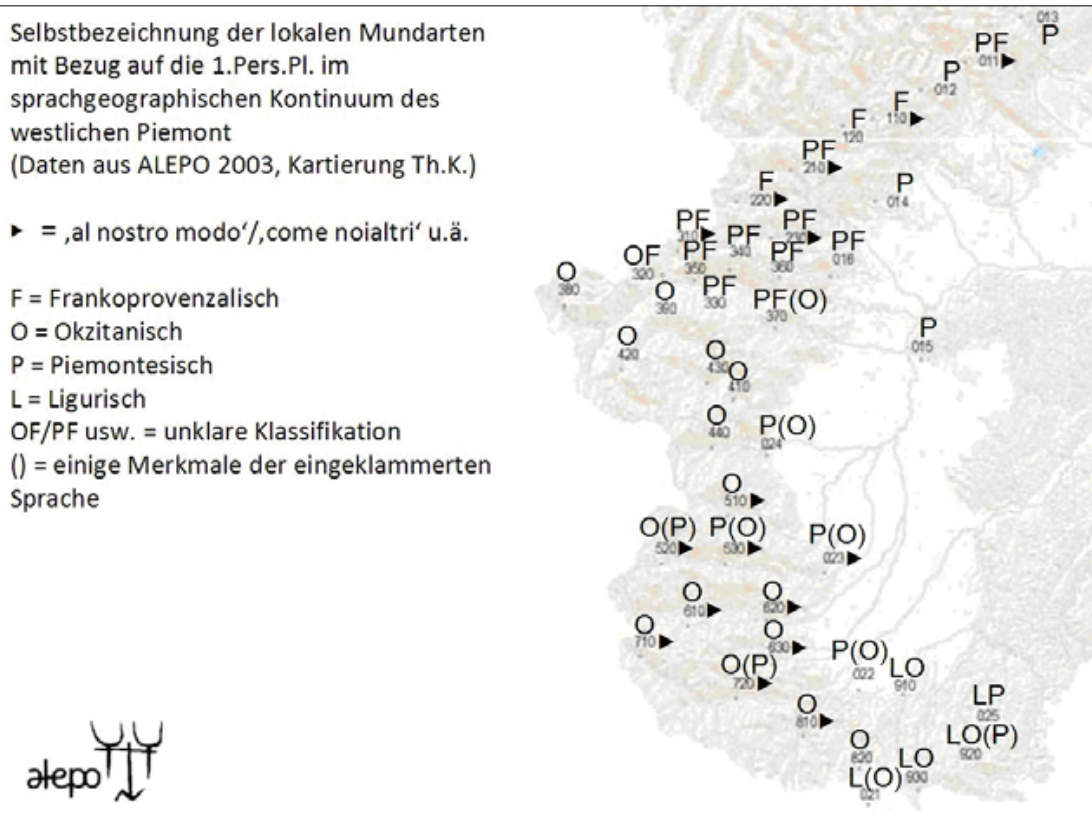

${ }^{10}$ What the cultural a $\mathrm{nth}$ ropolog u e Francesco Remotti says about the construction of identity in general holds also, and maybe in a more salient manner for the linguistic aspects of identity: "L'alterità è presente non solo ai margini, al di là dei confini, ma nel nocciolo stesso dell'identità. [...] costruire l'identità non comporta soltanto un ridurre, un tagliar via la molteplicità, un emarginare l'alterità, significa anche un far ricorso, un utilizzare, un introdurre, un incorporare dunque (che lo si voglia o no, che lo si dica o meno) l'alterità nei processi formativi e metabolici dell'identità" (2003, p. 63).
Perception of linguistic salience is, on the other hand, a source of linguistic dynamism, because it can lead to accommodation towards the interlocutor(s) or other speakers, and subsequently lead to spatial and/or social diffusion of the perceived features (cf. GILES; POWESLAND, 1997 [1975] and GILES; COUPLAND; COUPLAND, 1991). Accommodation is probably also possible in purely medial spaces; however, one should also consider the possibility of the opposite reaction: the insistence on sticking with one's own way of speaking. Corresponding studies on the names of migrant varieties are not present.

\section{Two perspectives: Auto- and Hetero-perception}

The concept of perception must also be refined and differentiated; the perception of the utterances of others, i.e. the hetero-perception, typically results in a changed self-perception or auto-perception with the reactions just mentioned ${ }^{10}$. In the sense of the cited graduated exclusivity of the "'we", it is important to bear in mind the spatial stratification of everyday life (SCHÜTZ; LUCKMANN, 1979, p. 63), because the concrete 
variation and the perception of shared varieties can correlate with a particular "reach" of the interaction, and therefore denote narrowly or widely-defined speaker groups and border areas with increasing foreignness. Adopting a very useful opposition proposed by Kenneth Lee Pike, one differentiates here between the group-internal (or emic) perspective, on the one hand, and group-external (or etic) perspective on the other (cf. KREFELD; PUSTKA, 2010, p. 22 and POSTLEP, 2010, p. 62). From the emic perspective, variety-internal variation is distinguished, e.g. when observing shifts in markers; in the etic, or variety-external perspective, universal phenomena of orality or effects of medial revolutions occur, such as the standardization processes that were set into motion with the spread of the printing press throughout Europe.

\section{Elementary constituents of the communicative space: glossotopes}

The evidence provided here result in not only the possibility, but also the necessity for locating language variation. "Location" here is not meant metaphorically, but is to be understood literally. The location of variation is not an abstract point in a matrix of formal parameters, but rather a speaker in his historical reification: with his repertoire of varieties (of more or fewer languages), with communicative routines that regulate the use of the different varieties available to the speaker within the network of his communication partners, and with the retroactive effects of these routines on his own repertoire. In this sense, each speaker, through the cultivation of his network, is the architect of his own spatial-communicational structure, and thereby, represents the minimal unit of communicative space for which - in proper spatially oriented terminology - the term 'glossotope' was coined (KREFELD, 2002, p. 159; 2004, p. 25). Thus, a category is proposed that does not stand in complete opposition, but is indeed in competition with the 'point' in the mapping of the dialectological space. In contrast to this one-dimensional concept that is only related to the dialectal system (language), this category is suited for mapping the complexity of communicative spaces. Indeed, different glossotopes can coexist in one and the same geographic location; on the one 
hand dialectal ones, but also recent 'migration glossotopes' created through speaker's mobility on the other. However, these recent constellations are also often already characterized by location-specific varieties, which develop rapidly due to the evolving multilingualism of the speakers, and the resulting language-contact-induced variation of the involved languages/ varieties. Naturally, individuals of identical origin at the same point of emigration do not live in identical glossotopes (cf. MELCHIOR, 2008).

From the glossotopic intertwining of the more-orless divergent speakers with their respective, narrowed 'I-horizons' emerges the dynamic and variable communicative space with its partly converging, partly competing and conflicting 'WE-horizons' and the possibility of corresponding varieties. In this sense, variational and variety linguistics of the communicative space are the object of a comprehensive 'glossotopia'. As Leibniz expressed it: "Concisely stated, space is what results from places when you consider them together (LEIBNIZ, [1716] 2006, p. 69)."

\section{REFERENCES}

ALEPO. CANOBBIO, S.; TELMON, T. (Hgg.). Atlante Linguistico ed Etnografico del Piemonte Occidentale. Presentazione e guida alla Lettura. Turin: Priuli.Ethnologue. Disponível em: < http://www. ethnologue.com/ >. Acesso em: 11 jan. 2015.

GILES, H.; POWESLAND, P. F. Accommodation theory. In: COUPLAND, N.; JAWORSKI, A. (Hgg.): A Sociolinguistics Reader. Macmillan: Basingstoke, [1975] 1997. p. 232-239.

GAUCHAT, L. Gibt es Mundartgrenzen? Archiv für das Studium der Neueren Sprachen und Literaturen, n.111, p. 345-403, 1903.

L'unité phonétique dans le patois d'une commune. Aus romanischen Sprachen und Literaturen. Festgabe für Heinrich Morf, Halle an der Saale, p. 1-58, 1905.

GILES, H.; COUPLAND, N.; COUPLAND, J. (Hgg). The Contexts of Accommodatio n: Dimensions in Applied Sociolinguistics. New York/Cambridge: University Press, [1991] 2010.

HAUCHECORNE, F.; BALL, R. L'accent du Havre: un exemple de mythe linguistique. Langage et Société, n.82, p. 5-26, 1997. 
KOCH, P.; OESTERREICHER, W. Gesprochene Sprache in der Romania. Französisch, Italienisch, Spanisch. Berlin/New York: De Gruyter, 2011.

KREFELD, T. La dissociazione dello spazio comunicativo in ambito migratorio (e come viene percepita dai parlanti): $\mathrm{i}$ meridionali in Baviera. In: D'AGOSTINO, M. (Hg.): Percezione dello spazio e spazio della percezione. Palermo: CFSL, 2002. p. 157-172.

. Einführung in die Migrationslinguistik. Von der Germania italiana in die Romania multipla. - Tübingen: Narr, 2004.

.,Primäre', ,sekundäre' und ,tertiäre' Dialekte - und die Geschichte des italienischen Sprachraums. In: OVERBECK, A. u.a. (Hg.): Lexikon, Varietät, Philologie. Romanistische Studien Günter Holtus zum 65. Geburtstag. Berlin/Boston: De Gruyter, 2011a. p. 137-147.

. Sag mir, wo der Standard ist, wo ist er (in der Varietätenlinguistik) geblieben?. In: SCHMIDT, S. D. u.a. (Hrsg.) (2011): Rahmen des Sprechens. Beiträge zu Valenztheorie, Varietätenlinguistik, Kreolistik, Kognitiver und Historischer Semantik. Peter Koch zum 60. Geburtstag. Tübingen: Narr, $2011 \mathrm{~b}$. p. 101-110.

„Sprachliche Variation im kommunikativen Raum: Neun Anhaltspunkte“. In: BERNSEN, M.; EGGERT, E.; SCHROTT, A. (Hrsg.). Historische Sprachwissenschaft als philologische Kulturwissenschaft. Bonn: V\&R unipress, 2015. p. 393-403.

KREFELD, T. L'immédiat, la proximité et la distance communicative. In: POLZIN-HAUMANN, C.;SCHWEICKARD, W. (Hgg.). Manuel de linguistique française. Berlin: De Gruyter, 2015a. p. 262-274.

KREFELD, T.; PUSTKA, E. Für eine perzeptive Varietätenlinguistik. In: KREFELD; PUSTKA (Hgg.): Perzeptive Varietätenlinguistik. Frankfurt: Lang, 2010. p. 9-30.

LEIBNIZ, G. W. Briefwechsel mit Samuel Clarke. In: DÜNNE, J.; GÜNZEL, S. (Hgg.): Raumtheorie. Grundlagentexte aus Philosophie und Kulturwissenschaft. Frankfurt: Suhrkamp, [1716] 2006. p. 58-73. 
LENZ, A. N. Emergence of Varieties through Restructuring and Reevaluation. In: AUER, P.;SCHMIDT, J. E. (Hgg.): Language and Space. An International Handbook of Linguistic Variation. Volume 1: Theories and Methods. Berlin: De Gruyter, 2010. p. 295-315.

MELCHIOR, L. Sù pes Gjermaniis: Zwischen Dissoziation und Integration: ommunikationsräume friaulischer Einwanderer in Bayern. Frankfurt: Lang, 2008.

MULJAČIĆ, Ž. Standardization in Romance. In: POSNER, R.; GREEN, J. N. (Hgg.): Bilingualism and Linguistic conflict in Romance, Trends in Romance Linguistics and Philology 5. Den Haag: Mouton, 1993. p. 77-116.

POSTLEP, S. Charrem altramén - Ein aragonesisches 'Randproblem' zwischen aragonés oriental und catalán occidental. In: KREFELD, T.; PUSTKA, E. (Hgg.): Perzeptive Varietätenlinguistik. Frankfurt: Lang, 2010. p. 61-102.

PURSCHKE, C.: Regionalsprache und Hörerurteil. Grundzüge einer perzeptiven Variationslinguistik. Stuttgart: Steiner, 2011.

REMOTTI, F. Contro l'identità. Bari: Laterza, [1996] 2003.

SCHMIDT, S. C. Das toscano und seine diatopische Variation. Untersuchung zur Wahrnehmung florentinischer und pratesischer Sprecher. München: unveröff. MA-Arbeit LMU, 2003.

SCHÜTZ, A.; LUCKMANN, T. Strukturen der Lebenswelt. Bd. 1. Frankfurt: Suhrkamp, 1979.

SINNER, C. Varietätenlinguistik. Eine Einführung. Tübingen: Narr, 2014.

STEHL, T. Funktionale Variationslinguistik. Untersuchungen zur Dynamik von Sprachkontakten in der Galloromania und Italoromania. Frankfurt: Lang, 2012.

TERRACINI, B. Il parlare d'Usseglio. Appendice I: La varietà nel parlare d'Usseglio. Archivio Glottologico Italiano, n.18, p. 105186, 1914-1922.

TOMASELLO, Michael. Origins of Human Communication. Massachusetts/London: Cambridge (Mass.)/ Bradford (London), 2008. 


\section{Resumo}

\section{Variação linguística induzida por migração no Espaço Comunicativo}

A migração é uma das causas fundamentais e de propagação do contato linguístico e de variação induzida por contato. Apesar da variação linguística induzida por contato não ser incomum, ela requer a descrição dentro de um modelo que torna possível contextualizar os dados linguísticos no espaço comunicativo. Isso requer a localização da variação da linguagem a partir do falante em seu contexto histórico (com seu repertório de variedades, com suas rotinas comunicativas e com o efeito dessas rotinas comunicativas em seu próprio repertório). Nesse sentido, o falante representa uma unidade mínima do espaço comunicativo ('glossotope') em que está inserido.

Palavras-chave: Variação da linguagem. Migração. Glossotopia. Percepção. Linguística variacional. 